\title{
Adaptive problems arising out of the progenitor's abandonment after Zika Congenital Syndrome
}

\author{
Problemas adaptativos decorrentes do abandono do progenitor após Síndrome Congênita do Zika \\ Problemas adaptativos derivados del abandono del progenitor después del Síndrome Congénito de Zika
}

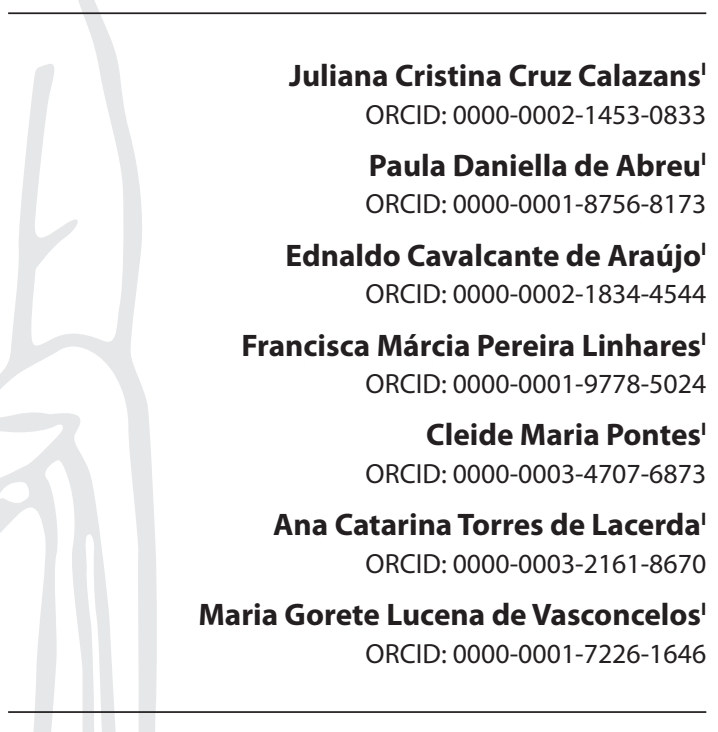

'Universidade Federal de Pernambuco. Recife, Pernambuco, Brazil.

How to cite this article: Calazans JCC, Abreu PD, Araújo EC, Linhares FMP, Pontes CM, Lacerda ACT, Vasconcelos MGL. Adaptive problems arising out of the progenitor's abandonment after Zika Congenital Syndrome. Rev Bras Enferm. 2020;73(Suppl 4):e20190602. doi: http://dx.doi.org/10.1590/0034-7167-2019-0602

Corresponding author:

Juliana Cristina Cruz Calazans

E-mail: julicris22@gmail.com

EDITOR IN CHIEF: Antonio José de Almeida Filho ASSOCIATE EDITOR: Hugo Fernandes

Submission: $02-23-2019$

Approval: 03-03-2020

\section{ABSTRACT}

Objective: to reveal the adaptive problems of the woman abandoned by the child's parent after Congenital Zika Syndrome, in the light of Roy's Adaptation Model. Method: a qualitative, descriptive study, based on Roy's Adaptation Model, developed with six women abandoned by their child's parent after Zika Congenital Syndrome diagnosis, through interview and Content Analysis technique. Results: adaptive problems appeared in nutrition, activity, rest, and protection patterns, due to limitations in self-care; self-concept, related to dissatisfaction with body image and personal being; in the role of transition role, through difficulties in taking over new roles and in interdependence, related to changes in affective needs. Final considerations: the overload of care for children with Congenital Zika Syndrome, added to the challenges of the abandoned woman by her child's parent, led to adaptive problems, showing their main difficulties of coping.

Descriptors: Congenital Abnormalities; Life-Changing Events; Caregivers; Mother-Child Relations; Nursing Theory.

\section{RESUMO}

Objetivo: revelar os problemas adaptativos da mulher abandonada pelo progenitor da criança após a Síndrome Congênita do Zika, à luz do Modelo de Adaptação de Roy. Método: estudo qualitativo, descritivo, fundamentado no Modelo de Adaptação de Roy, desenvolvido com seis mulheres abandonadas pelo progenitor do seu filho após diagnóstico da Síndrome Congênita do Zika, mediante entrevista e técnica de Análise de Conteúdo. Resultados: os problemas adaptativos se apresentaram nos padrões de nutrição, atividade, repouso e proteção, devido às limitações no autocuidado; no autoconceito, relativo às insatisfações com imagem corporal e ser pessoal; na função de papel de transição, através das dificuldades em assumir novos papéis e na interdependência, relacionada às mudanças nas necessidades afetivas. Considerações finais: a sobrecarga de cuidados à criança com a Síndrome Congênita do Zika, somada aos desafios da mulher abandonada pelo progenitor do seu filho, conduziu aos problemas adaptativos, evidenciando suas principais dificuldades de enfrentamento. Descritores: Anormalidades Congênitas; Acontecimentos que Mudam a Vida; Cuidadores; Relações Mãe-Filho; Teoria de Enfermagem.

\section{RESUMEN}

Objetivo: revele los problemas de adaptación de la mujer abandonada por los padres del niño después del Síndrome de Zika Congénito, a la luz del Modelo de Adaptación de Roy. Métodos: estudio cualitativo, descriptivo, basado en el Modelo de Adaptación de Roy, desarrollado con seis mujeres abandonadas por los padres de sus hijos después del diagnóstico de Síndrome de Zika Congénito, a través de una entrevista y una técnica de Análisis de Contenido. Resultados: los problemas de adaptación aparecieron en los patrones de nutrición, actividad y descanso y protección, debido a limitaciones en el autocuidado; autoconcepto, relacionado con la insatisfacción con la imagen corporal y el ser personal; en el rol de transición, a través de dificultades para asumir nuevos roles y en la interdependencia, relacionados con cambios en las necesidades afectivas. Consideraciones finales: la sobrecarga de atención para niños con Síndrome Congénito del Zika, sumado a los desafíos que enfrentan las mujeres abandonadas por los padres de sus hijos, condujo a problemas de adaptación, destacando sus principales dificultades de afrontamiento.

Descriptores: Anomalías Congénitas; Acontecimientos que Cambian la Vida; Cuidadores; Relaciones Madre-Hijo; Teoría de Enfermería 


\section{INTRODUCTION}

Congenital Zika Syndrome (CZS) is characterized by a series of fetal complications triggered by problems in the formation or development of the Central Nervous System (CNS), after vertical transmission, resulting from by infection Zika virus in the maternal organism ${ }^{(1-5)}$. In Brazil, from 2015 to 2018, 16,028 suspected cases were reported, of which 3,194 were confirmed, with the highest number of cases in the Northeast (59.7\%) and the highest prevalence in the State of Pernambuco $(16.7 \%)^{(6)}$.

Since it is a Syndrome recently discovered, it caused negative repercussions to families, because affected children have uncertain prognosis, which may have precipitated reactions in some isolation or abandonment of the family ${ }^{(7)}$. Abandonment results from denial, renunciation or rejection of care and living with the child ${ }^{(8-9)}$.

Faced with the reality of having a child with special needs and without the help of the child's father, mothers needed to experience acceptance processes to adapt. However, without adequate support, adaptive problems may arise that will reflect on individual health and the establishment of bonds and care for their child(7,10).

Roy's Adaptation Model (RAM) considers that the individual interacts with the environment, stimuli and coping mechanisms, forming a system of inputs, outputs, control, and feedback. Among the stimuli received by the person, Roy categorizes them into focal, contextual, and residual. The focal can be characterized as having the greatest impact, since it is what affects the human being immediately. The contextual are the influences on the experienced situation. The residual are additional factors, the effect of which is not always clear. When associated with the level of adaptation, stimuli will interact with the input system, with the variation in responses, being unique to each person ${ }^{(11-12)}$.

When considering the demands generated for mothers abandoned by their child's parent after CZS diagnosis and based on RAM, nurses can be a facilitator to support for care. Knowing the adaptive problems is important for the construction of nursing strategies consistent with the situation of these women, facilitating the reestablishment of coping processes and the integrity of their health. Therefore, this study sought to answer the following question: what are the adaptive problems of the woman abandoned by her child's parent after the CZS, under in the light of RAM?

\section{OBJECTIVE}

To reveal the adaptive problems of the woman abandoned by the child's parent after Congenital Zika Syndrome diagnosis, in the light of RAM.

\section{METHODS}

\section{Ethical aspects}

The data were constituted from a dissertation developed in the Graduate Program in Nursing of the Universidade Federal de Pernambuco (UFPE), whose project was approved by its Health Sciences Center's Research Ethics Committee. It complied with Resolution 466/2012, which aims to guarantee the rights and duties of employees, the scientific community and the State.
Participant anonimity was ensured, the identities were replaced by the code name "Mother", followed by the number of the order in which they were interviewed.

\section{Theoretical-methodological framework}

This is a study based on the RAM theoretical framework. The study considers the individual as a set of interrelated systems, that through the environment, internal stimuli and coping mechanis$\mathrm{ms}$ are able to develop positive or negative responses to stress situations, viewed through four adaptive modes: physiological, self-concept, role function, and interdependence ${ }^{(11-12)}$.

\section{Type of study}

This is a qualitative, descriptive and exploratory study ${ }^{(13)}$. The design and description of this study are in accordance with the Consolidated Criteria for Qualitative Study Reports ${ }^{(14-15)}$.

\section{Methodological procedures}

\section{Study setting}

The relevance of the choice of participants was considered for interview day, location, and time, in order to create greater comfort, security and freedom of speech. Thus, the study was conducted in the city of Recife, capital of Pernambuco (PE), Brazil, due to the choice of location by all participants. It is important to note that Recife was considered one of the pioneers in detecting cases of microcephaly and CZS, in addition to having a high number of reported cases ${ }^{(16)}$.

\section{Data source}

Six women participated in this study, who met the inclusion criteria: any age group, living in the Metropolitan Region of Recife, having at least one child with a confirmed diagnosis of CZS, and having suffered abandonment of the child's parent after diagnosis. Those who reported not having a marital relationship with the child's father before abandonment were excluded. For the sample selection, the snowball technique chain ${ }^{(17)}$ was used, variant of the sample for convenience.

This technique was chosen was due to the need to gather the population of interest, with peculiar characteristics or difficult to identify. Recruitment was carried out by indicating people who had similar characteristics, in order to meet the research objective. In accordance with the snowball technique, first contact was made with participants from a reference hospital in Pernambuco. At the time, an invitation was made to contribute as a locus of research. Seed indications contributed to the recruitment of the following chains, that, after the end of the interview, were invited to indicate other possible participants ${ }^{(17)}$.

After confirming the invitation, a face-to-face meeting was scheduled according to the availability and location of the participants' choice. After the end of each interview, three to six coded coupons were distributed to their eligible peers containing the following questions: do you know any mother who was abandoned by her partner after CZS diagnosis? What is her name and where can I find her? Candidates for participation in the study 
were initially invited by telephone. Participants were progressively included, until the saturation of the answers was obtained. This occurs when there is deepening and comprehensiveness of the speeches to the proposed questions ${ }^{(18)}$.

The contact network consisted of three waves, with a total of 15 indications. However, five mothers did not accept to participate in the study; with one of them it was not possible to establish contact; and three did not meet the inclusion criteria, leaving a final sample of 6 women. Women who refused to participate in the study reported lack of interest, overload of invitations to further research on CZS or reported that they preferred to remain hidden due to threats from their child's parent, despite having been oriented about their anonymity in research.

\section{Data collection and organization}

Individual interviews were carried out from May to November 2017, in a private location, chosen by the participant, being carried out at the mothers' homes, with the exception of one participant who opted for the meeting in a public building of the Recife. The interviews were guided by the following question: how is it for you to take care of your child, abandoned by the father, after being diagnosed with CZS? The average duration was from 20 to 60 minutes.

After conducting the interviews, the reports were transcribed in full and submitted to analysis. Interview validation took place with the help of a second researcher, who, after the end of the collection, also transcribed the speeches from the audios, to carry out the comparison with the first transcriptions and corrections of possible errors ${ }^{(19)}$.

\section{Data analysis}

From the Content Analysis technique, the corpus was analyzed by carrying out text screening and exhaustive reading. The analysis was based on RAM in order to identify adaptive problems, presenting women's behaviors and environmental stimuli. Finally, an infographic map was constructed as a synthesis of the identified mothers' adaptive processes and problems, with a view to combining synthesis and dynamism with the content worked on. For the assembling and construction of this map, the nuclei of meaning referring to the initial stimuli, in the entry process, the coping mechanisms, such as the regulatory processes, and the exits, as the adaptive problems, were selected.

\section{RESULTS}

The study participants were aged between and 25 at 34 years old, education between elementary and complete higher education, family income equivalent to 1 minimum wage and a woman reported not having a religion. The relationship time with the child's parent was 1.5 to 13 years, one married and five in common law union. As for the family constitution, three mothers had, in addition to the child with CZS, from two to five children, with the age group from 4 to 17 years old. Children with CZS were between 1.5 at 2 years old.

Based on the analysis of the statements, according to RAM, two categories were considered called "Interacting with the environment and stimuli" and "Revealing adaptive problems."

\section{Interacting with the environment and stimuli}

The environment was represented by the physical and circumstantial conditions in which the mother lived with her child, so, when these conditions were not adequate, they caused discomfort, insecurity and uneasiness. A fact evidenced in the reports:

[...] this house here needs a renovation, but I am not able to fix it [...]. (Mother 1)

[...] where I live it is known to be a very violent area, I was afraid to sleep, without any security, I was scared to death [...]. (Mother 2)

The birth of a child with CZS and the abandonment of the child's parent after diagnosis was considered as the focal stimulus. It is noteworthy that the way in which some mothers received the diagnosis of malformation by health professionals, also brought problems to their adaptation process.

[...] the doctor did not say that B. [baby] had microcephaly, she called me and said that $B$. would be demented when she grew up ... so she said "Look mom, this metric ribbon proves that your daughter has a smaller head than normal, so she will vegetate, she will not eat, she will not walk, she will not do anything and it may not last long. So, I would look at the tape measure and wonder why a tape measure defines all of this". (Mother 2)

In this study, mothers reported lack of support from the child's father and aggressive ways of dealing with the new reality:

[...] / always thought I would count on him [the child's father] and when I needed him most, he turned the back to me (Mother 5)

[...] the father came and said that I had better choose either he who was the father or the demon who was the child [...]. (Mother 3)

Support networks and resources used by mothers to establish their adaptation were contextual stimuli:

Now I have adapted, there are my parents who help me, so, for me it was difficult at first, it was very difficult, but now I have adapted [...]. (Mother 4)

God is helping me and God has always been helping me, blessing me, always putting an angel in my path [...]. (Mother 5)

It was observed in this study that, in addition to the social support network, mothers used the belief in a Higher Being as the main resource to find strength to adapt to the current reality:

[...] it was heavy, it was a bit of a thump, because it was all new, again and alone this time, but I'm still working on it thanks to God, without his help [child's father], only with the help of God himself and ready, and the people who already help people from other NGOs. (Mother 6)

\section{Revealing adaptive problems}

After the interaction with the environment and the stimuli, mothers suffered influences in their physiological modes, self-concept, role function and interdependence, from their behavioral responses were identified the adaptive problems. 
Regarding the physiological mode, the participants had difficulties in taking care of their own health because they fully take care of the child's needs, presenting problems in meeting the standards of nutrition, activity, rest and protection, showing the adaptive problems of nutrition less than the organic needs and strategies of inefficient coping for the altered means of ingestion, according to the statements:

[...] with the rush runs, until today I go out without even having coffee [...]. (Mother 1)

[...] there are days when I go out without eating and come back without eating. (Mother 5) [...] / lost seventeen kilograms [...]. (Mother 6)

In the pattern of activity and rest, mothers showed physical wear due to the burden of care for children with special needs, revealing the following problems: potential for sleep pattern disorders, fatigue, inadequate pattern of activity and rest. In verbalizations, the exhaustive routine of mothers at the beginning of the day was evidenced:

My tiredness was visible, visible ... the burden is very high [...]. (Mother 1)

[...] I left my house at three-forty in the morning and arrived at ten at night tired. (Mother 5)

\section{[...] I would stay up all night, my fear was that she would have a seizure and I wouldn't see it, so when I dozed off, I was alert, it was that very light sleep, I spent about 4 months without sleeping right [...]. (Mother 2)}

Regarding the protection standard, mothers presented inefficient coping with changes in the immune status:

[...] I got the flu and I haven't been feeling well for two months [...]. (Mother 3)

[...] very low immunity, because I didn't take care of myself at all, I was sick sometimes and even though I was taking care of her, I couldn't help it, right. (Mother 2)

In the self-concept mode, it was observed that the way women viewed their physical body was with body image dissatisfaction, showing the following adaptation problems: Body image disturbance and Loss.

[...] it was very heavy, it was very fat, very tired ... I had no way of taking care of the body at all ... I didn't even have time to take along shower... so I didn't take care of myself in no way, I was not careful at all... I didn't have time for anything, for nothing at all ... I felt like garbage [...]. (Mother 2)

As for the personal being, mothers presented anxiety, impotence, and low self-esteem. These factors can be seen in the following reports:
[...] I was like, with a depression ... down ... really, really, really down. I try to lift my head and move on to continue taking care of my son [...]. (Mother 4)

Abrupt change in life sometimes results in a loss of meaning and difficulties in adapting:

[...] in the past, I just kept settling in, doing this and that other, going out ... nowadays I don't even feel like it anymore, because like it or not, there isn't even time [...]. (Mother 6)

In the role function, there was a search for the balance of roles of being a mother abandoned by the parent of her son and caregiver of a child with CZS, reflecting major changes in their lives and problems in the role transition:

In the beginning it was very difficult ... first, nothing was known ... until today, so, not much is known, but in the beginning, I didn't know anything about how it would be ... what was going to happen [...]. (Mother 1)

[...] you never think that your child will come with a disability, you think of a perfect child ... I couldn't breastfeed, I couldn't hear her crying and that was very difficult for me [...]. (Mother 2 )

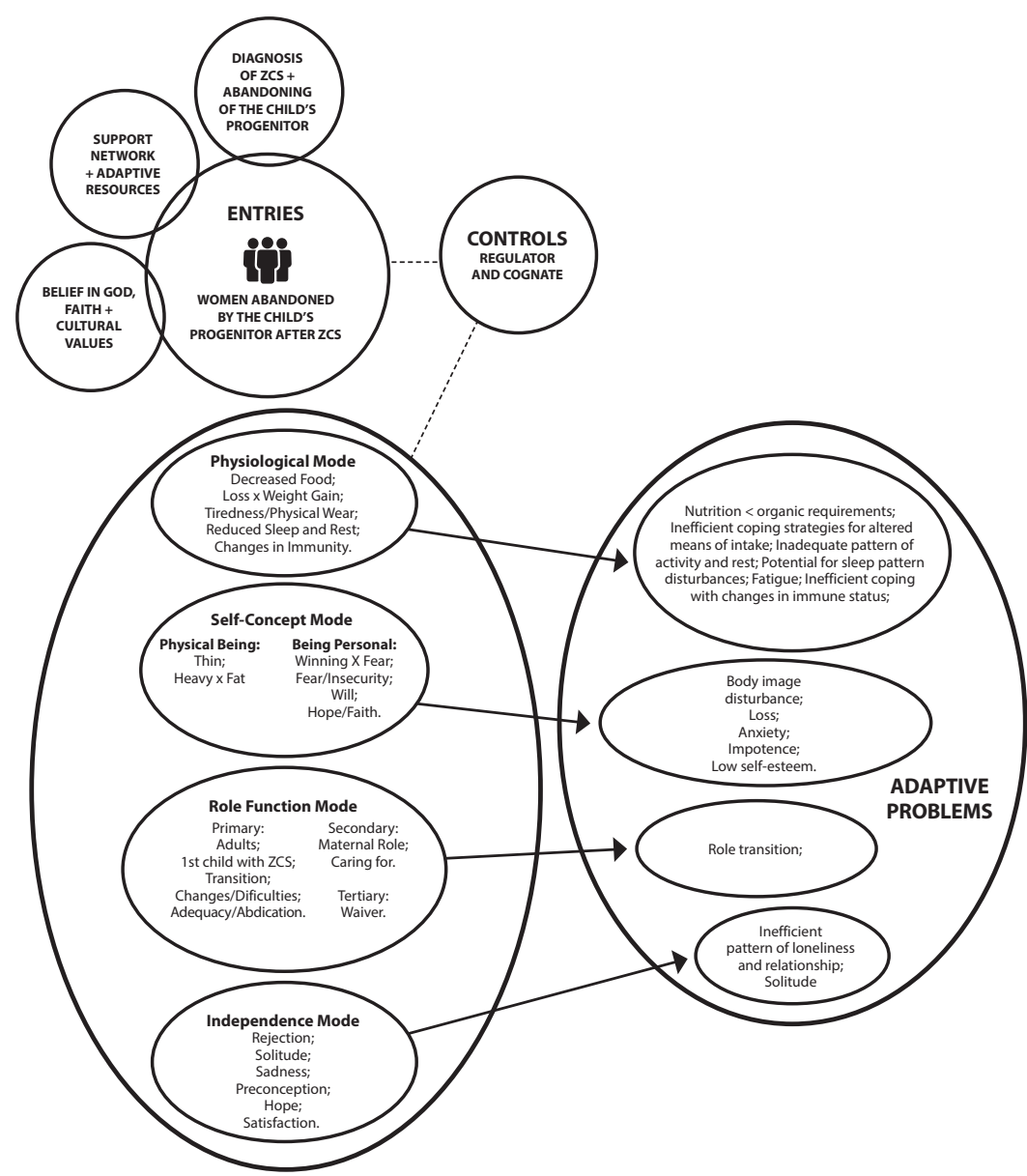

Figure 1 - Infographic map of the adaptive problems of women abandoned by their child's parent after Zika Congenital Syndrome, in the light of Roy's Adaptation Model, Recife, Pernambuco, Brazil 
In the interdependence mode, changes in affective needs were evidenced through the problems "Inefficient pattern of loneliness and relationship" and "Loneliness":

\section{[...] I felt very rejected ... feeling lonely, feeling useless. (Mother 4)}

The people say that our children are children of the mosquito, that my daughter looks like a frog, my daughter doesn't look like a frog! Even if she came with only one arm, only with one leg, love would be the same...there are people who say that these children are daughters of the devil, say that these boys look like a dog, it all revolts us [...]. (Mother 5 )

As shown in Figure 1, the infographic map is presented with the synthesis of the process of building coping mechanisms until the mothers' adaptive problems are released.

\section{DISCUSSION}

When comparing the results obtained in this research and relating them to literature, it becomes possible to support nursing care. Thus, nurses facing the processes of transitions and repercussions experienced by the adaptive problems of the woman abandoned by the child's parent after CZS can facilitate the recognition of stimuli and influences in each adaptive mode, promote resources to cope with the situation, and direct planning health education congruent with the specific needs of each woman.

Women abandoned by the child's parent after CZS deal with feelings of rejection by their partner and sometimes neglect self-care due to their children's needs and coping with their fears, all of this is also related to ignorance the new reality and to fight against social prejudice. Given the context of exclusion and the challenges of specific child care, it is necessary for nurses to act in promoting adaptive processes ${ }^{(13,20)}$, considering the internal and external stimuli related to these.

Mothers presented congruences in their life histories, because in addition to having contracted the infection of a virus from an epidemic and suffering the abandonment of their children's parents, all were of low income and lived in locations lacking basic sanitation. When considering the potency of the virus, the entire population would be able to become ill. However, the precarious life of some risk poles around large cities, lacking basic infrastructure, weakens people to the mosquito, marking groups of women who had their lives precarious by the epidemic of the Zika virus (21-22).

The environment in which mothers were inserted with their child, is one of the essential elements of RAM, as it represents the space that involves the person within the adaptive system and through the influences of their conditions can cause damage to the individual's health ${ }^{(12,23)}$. Roy considers the person in the Adaptation Model to be a social, mental, spiritual and physical being, affected by stimuli from the environment.

Women abandoned by their child's parent after CZS interacted with the environment and focal, contextual and residual stimuli that influenced the construction of coping mechanisms. Living new situations can generate reactions and feelings that lead to changes in a person's habits, therefore, for a mother, receiving a diagnosis of a malformation in the child can lead to negative feelings that should be considered by health professionals, especially nurses, in the establishment of links and support ${ }^{(23-25)}$.

Coping with the diagnosis is more difficult when it is rudely or mistakenly passed on by health professionals, impairing the understanding of the child's health situation ${ }^{(24)}$. In addition, the negative reactions of the child's father to malformation brought to these women situations of violence ${ }^{(26)}$, which added to abandonment, culminated in the increase of maternal suffering.

Experiencing the care of a child with malformation without the help of a spouse increases the needs of the social support network. Adequate support favors mothers to face the new reality, to restructure their family and to deal with new situations ${ }^{(27)}$. Faith and spirituality can also act as a foundation for human beings and give them support ${ }^{(28)}$.

Faced with the interaction between stimuli and the environment, the individual will develop their responses through behaviors, which can be characterized as adaptive responses or adaptive problems ${ }^{(11)}$. When taking over the role of primary caregiver for their children with CZS, the women in this study reported a decrease in self-care.

Similar studies have shown that providing care to children with neurological problems reduces maternal health levels ${ }^{(29-34)}$. The loss of self-care is associated with the fact that they are solely responsible for the demands of the family, the socioeconomic status of these women was also a limiting factor for the establishment of healthy behaviors, such as minimally adequate food and intervals of sleep and rest.

The self-concept mode promotes several situations that can influence the adaptive state ${ }^{(11)}$, since for these women to experience the reality of having a child with a recently discovered syndrome and suffering the abandonment of the child's father, permeated psychological impacts that can lead to emotional instability, insecurity, mood swings and physical ailments, thus the collaborators presented adaptive problems in the perception of the physical being and the personal being, as observed in other studies ${ }^{(31,35-36)}$.

Every human being needs to change roles according to new situations experienced and may exhibit negative behavior that leads to some adaptation problem ${ }^{(12)}$. For mothers, the role transition mode was marked by changes in all of their life habits, generated by the needs to adapt to the child's conditions, as indicated in other studies ${ }^{(29-30,35-36)}$.

Malformation diagnosis shock and limitations of children with CZS increased the difficulties in breastfeeding, similar to what is found in the literature ${ }^{(36)}$. Being able to breastfeed children with malformation may be an indication that the child shows improvement in his condition, reducing feelings of insecurity and anxiety of mothers ${ }^{(37-38)}$. However, in the present research, difficulties were mentioned for the practice of breastfeeding.

The interdependence mode promotes the individual's relationships and affective needs ${ }^{(11-12)}$. The adaptive problems revealed in this mode were generated essentially by the abandonment of the child's parent in the face of the challenge of being the mother of a child with CZS. They experienced the end of their relationship with their partner as a destruction of their emotional and personal life. The mothers of this study expressed feelings of profound loneliness, similar to the findings of another study ${ }^{(39)}$. Moreover, 
they needed to learn to circumvent society's prejudice against their child's malformation. Families of children with congenital abnormalities constantly suffer from prejudiced comments and postures ${ }^{(25)}$. Prejudice is surrounded by the child's aesthetic issues, valued by social and cultural standards and has a strong influence on the individual's behavior, given the possibilities of generating strangeness and teasing by other people, leading the subject and his family to social exclusion ${ }^{(40)}$.

In this context, nurses, together with the multiprofessional team, must be prepared to identify the needs of support of these women and offer adequate support for health education, with the purpose of preparing the mother for the current reality and strengthening the affective bond with the child ${ }^{(20,28)}$. Nursing professionals can help the family through support and guidance based on their technical-scientific knowledge associated with their practical experience, educating about the child's health conditions, care, procedures, and treatments ${ }^{(28-29)}$.

Based on the vulnerability factors of women abandoned by their child's parent after CZS, nurses will be able to identify gaps and weaknesses and, thus, improve the planning of health interventions and appropriate educational strategies. Stimulating the empowerment of these women, so that they can properly care for their child, demand their rights as citizens, dialogue with the social support network and mobilize resources appropriate to their child's demands ${ }^{(29,37-38)}$.

\section{Study limitations}

This study had as difficulties the lack of research involving the theme of women/mothers abandoned by their child's parent. Thus, it emphasizes the importance of conducting research related to adaptive modes, stimuli and coping strategies of women abandoned by the child's parent after the diagnosis of malformation and the paternal adaptive stimuli and problems in face of the child's malformation.

\section{Contributions to nursing, health and public policies}

Nursing is configured as a science of care, especially for people, families or communities in situations of health vulnerability. Therefore, the knowledge of the adaptive problems developed after the diagnosis of CZS and the abandonment of the child's parent, based on RAM, will contribute to the planning of integrated actions through the Nursing Process. It is necessary to promote spaces for debates and offer care consistent with the specific needs of these mothers, in order to reestablish their adaptive processes and their health integrity. The knowledge of these mothers' adaptive problems, based on the Nursing Theory, gives it its own language to nurses, as well as allowing the improvement of care and greater professional autonomy.

\section{FINAL CONSIDERATIONS}

Through this study, the following adaptive problems were revealed in women abandoned by the child's parent after to CZS: nutrition less than organic needs, inefficient coping strategies for altered modes of ingestion, potential for sleep pattern disorders, fatigue, inadequate pattern of activity and rest, inefficient coping with changes in immune status, disturbance of body image, loss, anxiety, impotence, low self-esteem, problems in the role transition, loneliness and inefficient pattern of loneliness and relationship.

Experiencing the care of a child with a malformation without the support of a spouse results in a greater burden of tasks for mothers, which worsens from the context of vulnerability resulting from socioeconomic and emotional difficulties. Humanized care of nurses, associated with RAM, will outline health promotion strategies, which should be congruent with the specificities of each woman/mother, in order to achieve positive adaptive responses. It is necessary to have detailed knowledge of coping mechanisms of these women by nurses for the effectiveness in the construction of diagnoses and interventions aimed at the adaptation process.

\section{REFERENCES}

1. Calvet G, Aguiar RS, Melo AS, Sampaio AS, Filippis I, Araujo ESM, et al. Detection and sequencing of Zika virus from amniotic fluid of fetuses with microcephaly in Brazil: a case study. Lancet Infect Dis. 2016;16(6):653-60. doi: 10.1016/S1473-3099(16)00095-5

2. Melo ASO, Malinger G, Ximenes R, Szejnfeld PO, Sampaio SA, Filippis AMB. Zika virus intrauterine infection causes fetal brain abnormality and microcephaly: tip of the iceberg? Ultrasound Obstet Gynecol [Internet]. 2016[cited 2019 Jan 10];47:6-7. Available from: https://doi.org/10.1002/ uog. 15831

3. Miranda-Filho DB, Martelli CM, Ximenes RA, Araújo TV, Rocha MA, Dhalia R, et al. Initial description of the presumed congenital Zika Syndrome. Am J Public Health [Internet]. 2016[cited 2019 Jan 10];106(4):598-600. Ajphspecial section: Zika. Available from: https://ajph. aphapublications.org/doi/10.2105/AJPH.2016.303115

4. Ribeiro BNF, Muniz BC, Gasparetto EL, Ventura N, Marchiori E. Congenital Zika syndrome and neuroimaging findings: what do we know so far? Radiol Bras. 2017;50(5):314-22. doi: 10.1590/0100-3984.2017.0098

5. Ventura CV, Maia M, Ventura BV, Van Der Linden V, Araújo EB, Ramos RC, et al. Ophthalmological findings in infants with microcephaly and presumable intra-uterus Zika virus infection. Arq Bras Oftalmol. 2016;79(1):1-3. doi: 10.5935/0004-2749.20160002

6. Ministério da Saúde (BR), Secretaria de Vigilância em Saúde. Monitoramento integrado de alterações no crescimento e desenvolvimento relacionadas à infecção pelo vírus Zika e outras etiologias infecciosas, até a Semana Epidemiológica 28/2017[Internet]. 2018[cited 2019 Jan 10];4(28). Available from: http://portalarquivos2.saude.gov.br/images/pdf/2018/junho/29/Monitoramento-integrado-de-alteracoes-nocrescimento-e-desenvolvimento-relacionadas-a-infeccao-pelo-virus-Zika.pdf

7. Melo DGS, Silva HF, Moura ITT, Barbosa SS. Aceitação paterna diante o diagnóstico de microcefalia. Psicologia. Pt. 2017 
8. Braga MMS, Scumacher AA. Direito e inclusão da pessoa com deficiência: uma análise orientada pela Teoria do Reconhecimento Social de Axel Honneth. Rev Soc Estado. 2013;28(2). doi: 10.1590/S0102-69922013000200010

9. Moreira LE, Toneli MJF. Abandono afetivo: afeto e paternidade em instâncias jurídicas. Psicol: Ciên Prof. 2015;35(4):1257-74. doi: $10.1590 / 1982-3703001442013$

10. Morilla CM, Cardoso CA, Caldas CT, Scarpellini ACAV, Santos PL. Family resources and promotion of development of children with cerebral palsy. J Hum Growth Dev. 2017;27(2):166-74. doi: 10.7322/jhgd.122707

11. Jones BL. Roy Adaptation Model: Sister Callista Roy. Nursing Theories: A Framework for Professional Pratice AN; 2005.

12. Roy SC, Andrews HA. Teoria da enfermagem: o modelo de adaptação de Roy. Lisboa: Instituto Piaget; 2001.

13. Minayo MCS. Scientificity, generalization and dissemination of qualitative studies. Ciên Saúde Coletiva. 2017;22(1):16-7. doi: $10.1590 / 1413-81232017221.30302016$

14. Maxwell JA, Miller B. Real and virtual relationship in qualitative data analysis. In: Maxwell JA. A realist approach for qualitative research. Los Angeles: SAGE Publications; 2012.

15. Booth A, Hannes K, Harden A, Noyes J, Harris J. Consolidated Criteria for Reporting Qualitative Studies COREQ. In: Moher D, Altman D, Schulz K, Simera I, Wager E, editors. Guidelines for reporting health research: a user's manual. Oxford: John Wiley \& Sons; 2014.

16. Secretaria Estadual de Saúde (PE), Secretaria de Saúde do Estado de Pernambuco. Casos e óbitos de dengue, chikungunya e zika: monitoramento dos índices de infestação. Recife, PE: Secretaria Estadual de Saúde [Internet]. 2017[cited 2019 Jan 10] Available from: http:// www.mppe.mp.br/mppe/attachments/article/7318/INFORME\%20ARBOVIROSES\%20SESPE\%20SE\%2003-2017.pdf

17. Polit DF, Beck CT. Fundamentos de pesquisa em enfermagem: avaliação de evidências para a prática da enfermagem. $7^{a}$ ed. Porto Alegre: Artmed; 2011.

18. Minayo MCS. Amostragem e saturação em pesquisa qualitativa: consensos e controvérsias. Rev Pesqui Qualit [Internet]. 2017 [cited 2019 Jan 10];5(7):1-12. Available from: https://edisciplinas.usp.br/pluginfile.php/4111455/mod_resource/content/1/Minayosaturacao.pdf

19. Sampierre RH, Collado CF, Lucio MPB. Metodologia de Pesquisa. 5a ed. Porto Alegre: Penso; 2013. p. 401-412.

20. Araújo BBM, Pacheco STA, Rodrigues BMRD, Silva LF, Rodrigues BRD, Arantes PCC. The nursing social practice in the promotion of maternal care to the premature in the neonatal unit. Texto Contexto Enferm. 2018;27(4):e2770017. doi: 10.1590/0104-07072018002770017

21. Diniz D. Zika virus and women. Cad Saúde Pública. 2016;32(5):00046316. doi: 10.1590/0102-311X00046316

22. Diniz D, Brito L. Zika virus disease epidemic: information and knowledge. Rev Eletron Comun Inf Inov Saúde [Internet]. 2016[cited 2019 Jan 10];10(2). Available from: www.reciis.icict.fiocruz.br.

23. Piexak DR, Backes DS, Backes MTS, Santos SSC, Gautério DP, Tomaschewski JG. Nursing faculty perceptions of the environment of human care. Rev Enferm UERJ. 2014;(22):489-93. doi: 10.1590/S0080-623420160000300006

24. Araújo YB, Reichert APS, Vasconcelos MGL, Collet N. Fragility of the social network of families of children with chronic disease. Rev Bras Enferm. 2013;66(5):675-81. doi: 10.1590/S0034-71672013000500006

25. Figueiredo LMF, Silva PCS, Souza ALT, Soares EA, Mesquita G. Ambivalent feelings of the family by the person with special needs. Arq Ciênc. Saúde [Internet]. 2014[cited 2019 Jan 10];21(1):60-5. Available from: http://repositorio-racs.famerp.br/racs_ol/vol-21-1//D-549-21(1)-(Jan-Mar-2014).pdf

26. Mendonça MFS, Ludermir AB. Intimate partner violence and incidence of common mental disorder. Rev Saúde Pública. 2017;(51):32. doi: 10.1590/s1518-8787.2017051006912

27. Pintanel AC, Gomes GC, Xavier DM. Mothers of visually impaired children: difficult and easy aspects faced in care. Rev Gaúcha Enferm. 2013;34(2):86-92. doi: 10.1590/S1983-14472013000200011

28. Sandor ERS, Marcon SS, Ferreira NMLA, Dupas G. Social support demands of families with children with cerebral palsy. Rev Eletron Enferm. 2014;16(2):417-25. doi: 10.5216/ree.v16i2.21112.

29. Brunoni D, Blascovi-Assis SM, Osório AAC, Seabra AG, Amato CAH, Teixeira MCTV, et al. Microcefalia e outras manifestações relacionadas ao vírus Zika: impacto nas crianças, nas famílias e nas equipes de saúde. Ciên Saúde Coletiva. 2016;21(10):3297-302. doi: 10.1590/1413-812320152110.16832016

30. Eickmann SH, Carvalho MDCG, Ramos RCF, Rocha MAW, van der Linden V, Silva PFS. Síndrome da infecção congênita pelo vírus Zika. Cad Saúde Pública. 2016;32(7):00047716. doi: 10.1590/0102-311X00047716

31. Ribeiro MFM, Sousa ALL, Vandenberghe L, Porto CC. Estresse parental em mães de crianças e adolescentes com paralisia cerebral. Rev Latino-Am Enfermagem [Internet]. 2014[cited 2019 Jan 10];22(3):440-7. Available from: http://www.scielo.br/pdf/rlae/v22n3/pt_0104-1169rlae-22-03-00440.pdf

32. Santos $D$, Pimenta MA, Bittencourt F, Nascimento $M C$, Fava $S M C L$, Calheiros $C A P$, et al. Prevenção da infecção pelo zika vírus nas gestantes. Rev Enferm UFPE. 2017;11(Supl. 12):5339-53. doi: 10.5205/1981-8963-v11i12a22917p5339-5353-2017

33. Gronning DMT, Solberg O, Holmstrom H, Landolt MA, Eskedal LT, Vollrath ME. Well-being in mothers of children with congenital heart defects: a 3-year follow-up. Qual Life Res. 2013;22(8):2063-72. doi: 10.1007/s11136-012-0326-0

34. Ribeiro MFM, Porto CC, Vandenberghe L. Estresse parental em famílias de crianças com paralisia cerebral: revisão integrativa. Ciên Saúde Coletiva. 2013;16(6):1705-15. doi: 10.1590/S1413-81232013000600022. 
35. Oliveira MC, Moreira RCR, Lima MM, Melo RO. Vivências de mães que tiveram filhos com microcefalia. Rev Baiana Enferm. 2018;32:e26350. doi: $10.18471 /$ rbe.v32.26350

36. Oliveira RMR. Uma abordagem sobre as dificuldades enfrentadas por mães na amamentação de crianças portadoras de fissuras lábiopalatinas. REBES [Internet]. 2016[cited 2019 Jan 10];4(2): 1-6. Available from: https://www.gvaa.com.br/revista/index.php/REBES/ article/view/3017/2500

37. Almesned S, Al-Akhfash A, Mesned AA. Social impact on families of children with complex congenital heart disease. Ann Saudi Med. 2013;33(2):140-143. doi: 10.5144/0256-4947.2013.140

38. Corrêa VAF, Acioli S, Tinoco TF. The care of nurses in the Family Health Strategy: practices and theoretical foundation. Rev Bras Enferm. 2018;71(Suppl 6):2767-74. doi: 10.1590/0034-7167-2018-0383

39. Moreira MCN, Mendes CHF, Nascimento M. Zika, protagonismo feminino e cuidado: ensaiando zonas de contato. Interface [Internet]. 2018[cited 2019 Jan 10];22(66):697-708.Available from: https://doi.org/10.1590/1807-57622017.0930

40. Freire IM, Pone SM, Ribeiro MC, Aibe MS, Pone MVS, Moreira MEL, et al. Síndromecongénito por el virus Zika en lactantes: repercusiones en la promoción de la salud mental de las familias. Cad. Saúde Pública. 2018;34(9):e00176217. doi: 10.1590/0102-311x00176217. 